\title{
EFFECT OF AQUEOUS PSIDIUM GUAJAVA LEAVES EXTRACT AS ANTI - HYPERGLYCEMIC AGENT
}

\author{
Omima M. R. Abu Elez ${ }^{(1)}$, M. A. Hammam ${ }^{(2)}$ and F.M. Elshony ${ }^{(2)}$ \\ (1) Pathological of Biochemistry Dept. - Medical Analysis- El-Roda Hospital- Damietta - \\ Egypt \\ ${ }^{(2)}$ Biochemistry Department- Faculty of Agricultural- Menuofia University-Egypt
}

Received: Nov. 14, 2021

Accepted: Nov. 21, 2021

\begin{abstract}
Background: Hyperglycemia is one of the serious problems that affect humans' lifestyle and require special treatments. Incorrect use of synthetic drugs results in side effects and other problems. Diabetic patients need safer and more effective antidiabetic drugs that decrease diabetic complications. Natural products are harmless due to conventional medicine can be inefficient (e.g. side effects and ineffective therapy).
\end{abstract}

Objective: Evaluate anti- hyperglycemic activity of aqueous leaves extract of Psidium guajava in hyperglycemic rats.

Methods: Adult males albino rats, weighting (140-150 grams) were assigned to one of four groups of six animals each $(n=6)$. Hyperglycemia induced by single dose intraperitoneal injection of STZ - NA (60 mg/kg - $110 \mathrm{mg} / \mathrm{kg}$, b.wt i.p.), the control groups was given distilled water, the experimental sub-groups were started one week later of STZ induction, then treated once daily by aqueous extract of Psidium guajava leaves until the end of experiment. Initially, blood samples were taken for measured glucose levels and HbA1c. The body weight, urine sugar and blood glucose levels were checked regularly.

Results: The polyphenolic of guava leaves extract was found to be (227.63 mg GAE /g. Ex), while flavonoids content was $(79.96 \mathrm{mg} \mathrm{QE} / \mathrm{g}$. Ex). However, it caused a significant decrease in blood glucose levels and $\mathrm{HbA1C}$ and other glycemic indicators.

Conclusion: aqueous extract of Psidium guajava leaves possess significant antidiabetic, and effective in lowering blood glucose level but lack hypoglycemic effect in hyperglycemic rats. Further studies warranted to elucidate possible mechanism(s) of action of the plant material.

Key words: Hyperglycemia, Hypoglycemia, Anti-hyperglycemic, Diabetic, Natural products, Psidium guajava, Streptozotocin and Rats.

\section{INTRODUCTION}

Hyperglycemia or abnormally high blood glucose one of the serious problems that require special treatments and can be affect humans' lifestyle. Hyperglycemia developing with impaired fasting glucose occurs when the bodies lack insulin or cannot use insulin properly causes an osmotic diuresis with significantly dehydration and electrolytes loss and directly causes glycation of proteins, lipids and nucleic acid, then injures cells and induces lipid peroxidation (Ahmadvand et al., 2014). Long- term hyperglycemia, leads to increased formation of reactive oxygen species (ROS) free radicals and increasing diabetic nephropathy complications associated with oxidative stress leads to serious macro-vascular and micro-vascular diabetic complications such as neuropathy, nephropathy, cardiac failure stroke, 
kidney failure and premature death (CDC, 2014).

The prevalence of diabetes higher in men than in women (CDC, 2015). Four out of five people with diabetes live in low- and middle-income countries and half of these people who died from diabetes under the age of 60 . Africa has the highest mortality rate due to diabetes compared to other parts of the world (IDF, 2012).

Incorrect use of synthetic drugs results in side effects and other problems (WHO, 2004). It is necessary to evaluate medicinal plants to support existing drugs in treating diabetes, which is very cheap, effective, harmless, safe and have biological activities to treat lifethreatening ailments with no side effects, low toxicity and economic (Grasas et al., 2018). Currently, many herbal medicines therapeutic available recommended for the treatment and improve diabetes (Altalhi et al., 2018). Among these plants is common guava leaves tree is a member of Myrtle family (Myrtaceae) (Naseer et al., 2018), genus: Psidium, species: guajava and common names of the plant are guava, goiaba, guayaba, etc. (Godebo et al., 2018). The leaves are wide, clear green in color, and have prominent veins (Rouseff et al., 2011).

Phytochemical analysis of guava leaves, revealed the presence of more than 20 isolated compounds include carotenoids, essential oils, fatty acids, anthocyanin's, coumarins, luteolin, and quercetin-like compound, terpenoids and triterpenes (Verma et al., 2018). Guava leaf contains high levels of copper, vitamins [C, B3, B6 and A], iron, tannin, saponins, alkaloid, glycosides, Morin, carbohydrates and dietary fiber. It contains also low calorie, minerals, antioxidants, polyphenol and flavonoids especially (quercetin) for prevention of cancers, aging, cell differentiation and apoptosis and immune enhancing, and prevent weight loss, maintain dental protection, reduce cholesterol levels, prevent stomach, prostate cancer and very effective in diarrhea treatment (Olaniyan, 2017).

The aim of work: Evaluate the hypoglycemic and anti- hyperglycemic activity and to prove in vivo antioxidant potential of aqueous leaves extracts of Psidium guajava in hyperglycemic rats.

\section{MATERIALS AND METHODS \\ Preparation of plant leaves extract}

Freshly, green leaves of psidium guajava obtained from the farm of (Agricultural of Research Centre- GizaEgypt). The leaves washed with water then dried in the shade away. The airdried plant material was ground using a mechanical grinder. $300 \mathrm{gm}$ of fine powdered material macerated in $3000 \mathrm{ml}$ of methanol $(80 \%)$ overnight for 72 hours, with frequent agitation. Then filtered, the residues were re-extracted in the solvent for another 2 times. The supernatant filtered twice; through cheese cloth then through filter paper (whatman No.1). Then evaporated by rotary evaporator under pressures at $40^{\circ} \mathrm{C}$ and dried using incubator at $40{ }^{\circ} \mathrm{C}$ for 24 hours to solid yield extract of guava leaves. The extract was preserved in sterile dark bottle at $4^{\circ} \mathrm{C}$ until further experiments.

\section{Determination of total polyphenols}

Total polyphenol contents of leaves were determined in ME using FolinCiocalteu reagent assay based on a colorimetric oxidation / reduction reaction, described by Chandra et al., (2014). The purplish compound absorbance was measured at $750 \mathrm{~nm}$, against distilled water as blank. Total phenolic contents expressed as $\mathrm{mg}$ Gallic acid equivalents (mg GAE) /g dry weight extract. 
Determination of total flavonoids content: The estimation of total flavonoids content was performed by aluminum chloride colorimetric assay with quercetin as a reference, described by Chang et al., (2002). The absorbance of the reaction mixture was measured at $415 \mathrm{~nm}$, using UV/ VIS- 1800 Series, spectrophotometer (Perkin Elmer, Lambda 2S, USA) against blank.

\section{Reducing Power assay}

Reducing power was performed as described in the method by (Ferreira et al., 2007). Ascorbic acid was used as reference standard. Absorbance was measured at $700 \mathrm{~nm}$ against blank solution.

\section{The experimental animals}

Healthy; Twenty four adult males albino rats have average weighted (140 150) $\mathrm{gm}$. All animals housed in the clean plastic ventilated cages and steel wire tops. Cages floor were covered with sawdust, which replaced every 2 days. All rats allowed acclimatizing to a new laboratory environmental for 7 days under laboratory conditions (12h-light / 12h-darkness cycle) in air-conditioned room $\left(22 \pm 2^{\circ} \mathrm{C}, \quad 45-75 \%\right.$ relative humidity). During the experimental period animals had ad libitum with free access to tap water and basal diet.

Seventy-two hours later of injection of STZ, the glucose levels measured from the tail vein after overnight fast. Hyperglycemia confirmed by using glucometer (Accu- Check, Germany). Only the rats considered as diabetic if fasting glycemia levels higher than 250 $\mathrm{mg} / \mathrm{dl}$. Hyperglycemia symptoms appeared after 72 hours as weight loss, polydipsia and polyuria. More assurance was obtained after detecting glucosuria. All studies were carried out after one week of STZ injection. Untreated Diabetic Group $(n=6)$ received basal diet and Treated Diabetic Group ( $n=12$ ) fed with the same diet supplemented with aqueous extract of guava leaves for $8^{\text {th }}$ weeks.

\section{Blood Samples:}

Initially, blood samples taken for measured glucose levels and HbAlc. The urine sugar, body weight and blood glucose levels were checked regularly. Blood examination at $8^{\text {th }}$ - weeks revealed difference between the diabetic control group and treated groups.

\section{Experimental protocol:}

\begin{tabular}{|l|l|l|}
\hline N & Group & Treatment \\
\hline I & Normal Control (NC) & $\begin{array}{l}\text { Non-diabetic rats, received daily basal diet and tap water } \\
\text { followed by a single orally 1ml of distilled water only, } \\
\text { twice weekly during the experimented period of eight- } \\
\text { weeks. }\end{array}$ \\
\hline II & Diabetic Control (DC) & $\begin{array}{l}\text { STZ-diabetic rats }(60 \mathrm{mg} / \mathrm{kg} . \text { b.wt. I.P.), received daily } \\
\text { basal diet and tap water followed by a single orally } 1 \mathrm{~mL} \\
\text { of distilled water only during the experimented period. }\end{array}$ \\
\hline III & D+ PGLE- 0.2 gm. & $\begin{array}{l}\text { STZ-diabetic rats received basal diet and tap water and } \\
\text { treated daily with single orally with aqueous guava leaves } \\
\text { extract only at a dose (0.2 g/kg b.w/ day). }\end{array}$ \\
\hline IV & D+ PGLE- 0.4 gm. & $\begin{array}{l}\text { STZ-diabetic rats received basal diet and tap water and } \\
\text { treated daily with single orally supplemented with } \\
\text { aqueous guava leaves extract only at a dose }(0.4 \mathrm{~g} / \mathrm{kg} \\
\text { b.w/day). }\end{array}$ \\
\hline
\end{tabular}


Omima M. R. Abu Elez, et al.,

\section{Estimation of biochemical parameters \\ Determination of fasting blood glucose levels}

At the Initial of the experiment, following the induction of STZ- induced rats, blood samples were taken from the base of rats' tail. The blood glucose level estimated using a standard glucometer (Accu - Check, Germany), then monitored periodically at end of $\left(2^{\text {nd }}\right.$ weeks, $4^{\text {th }}$ weeks and $8^{\text {th }}$ weeks) up to eight- weeks according to the enzymatic colorimetric method described by (Trinder, 1969).

\section{Estimation of glycosylated hemoglobin (HbA1c)}

Initial screening and final experiment, blood samples were obtained from the retro-orbital region of each rat into tubes containing EDTA as anticoagulant for estimation of HbA1c in whole blood according to method described by (Tietz, 1999).

\section{Urine glucose levels}

Urine glucose levels were weekly checked by urine glucose strips according to method described by NCCLS, (1992). Unpreserved urine samples may lose up to $40 \%$ of their glucose after 24 hours storage at room temperature.

\section{Determination of body weight gain}

The body weighed pre-treatment and once a weekly for all animals to adjust the dose of treatments. The body weight gain estimated by subtracting the initial body weight (before STZ induced) from the final body weight (post-treatment) of each rat.

\section{Statistical analysis}

Quantitative data results expressed as mean $\pm \mathrm{SD}$, one-way (ANOVA) test was employed for comparison each parameter among groups before and after the treatment. $\mathrm{P} \leq \mathbf{0 . 0 5}$ considered significant and $P>0.001$ considered highly significant for comparison the results.

\section{RESULTS AND DISCUSSION}

\section{Total polyphenols and flavonoids content}

Natural Polyphenols are secondary metabolites act as defense against different types of the stress; Protection of the plants against ultra-violet radiation, low soil fertility and changes of environmental temperature (Rodríguez et al., 2014). While flavonoids high redox potential, act as reducing agents, hydrogen donors, and scavengers of singlet oxygen (Tsao and Yang 2003).

Our results of total polyphenols and flavonoids content were illustrated in (Fig. 1). Guava leaves possess the highest antioxidant activity with higher total phenolic contents $(227.63 \mathrm{mg}$ GAE/g. Ex), and flavonoids content (79.96 $\mathrm{mg} Q \mathrm{Q} / \mathrm{g}$. Ex) in the present analysis.

Our results were accordance with those of El-Sayed and Said, (2017), who noted the extracts of guava leaves possess highest antioxidant capacities with higher total phenolic contents as well as the largest concentration of flavonols.

\section{Reducing power of various concentrations of guava leaves extract}

Reducing power assay measures the total reducing capability of antioxidants based on methanolic extract or Vit.C ability to reduce yellow ferric complex $\left(\mathrm{Fe}^{+3}\right)$ to blue ferrous complex $\left(\mathrm{Fe}^{+2}\right)$ ions by electron-donating antioxidants in acidic medium. The reducing power capacity of methanolic 
leaves extract of $p$. guajava as absorbance value of (0.606) was significantly lower than vitamin C (0.692) at $20 \mu \mathrm{g} / \mathrm{ml}$ (Fig. 2). At the highest concentration of phenolic up to the level $80 \mu \mathrm{g} / \mathrm{ml}$ guava leaves extract showed linearly highest activity (1.675). The reducing power of methanolic leaves extract of guava relatively increased with graded concentration. Increasing absorbance at $700 \mathrm{~nm}$ indicates an increase in reductive ability (Benzie and Strain, 1999).

The changes in fasting blood glucose levels induced by leaves extracts
As shown in Table (1), before firstweek of induction of diabetes in rats, there is not any significant difference among the groups in blood sugar levels. At initial of experiment (Zero- Time), blood sugar level after given STZ, increased to $282.3 \mathrm{mg} / \mathrm{dL}$ in diabetic control. According to the experiment results, normal fasting blood glucose in rats of this experiment was determined as $84.92 \mathrm{mg} / \mathrm{dl}$. Serum glucose level significantly increased $(p \leq 0.05)$ in diabetic control group as compared to normal control rats after second weeks, $4^{\text {th }}$ weeks and final weeks of treatment.

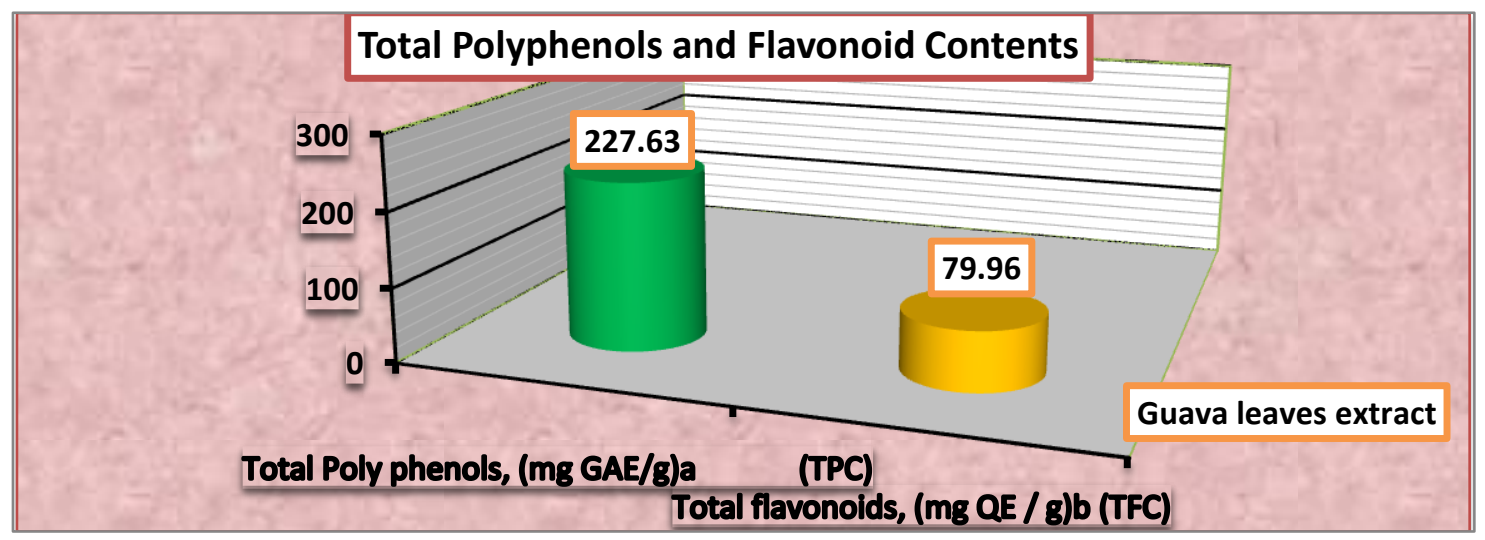

Fig. (1): Total polyphenols and flavonoids content in methanolic guava leaves extract

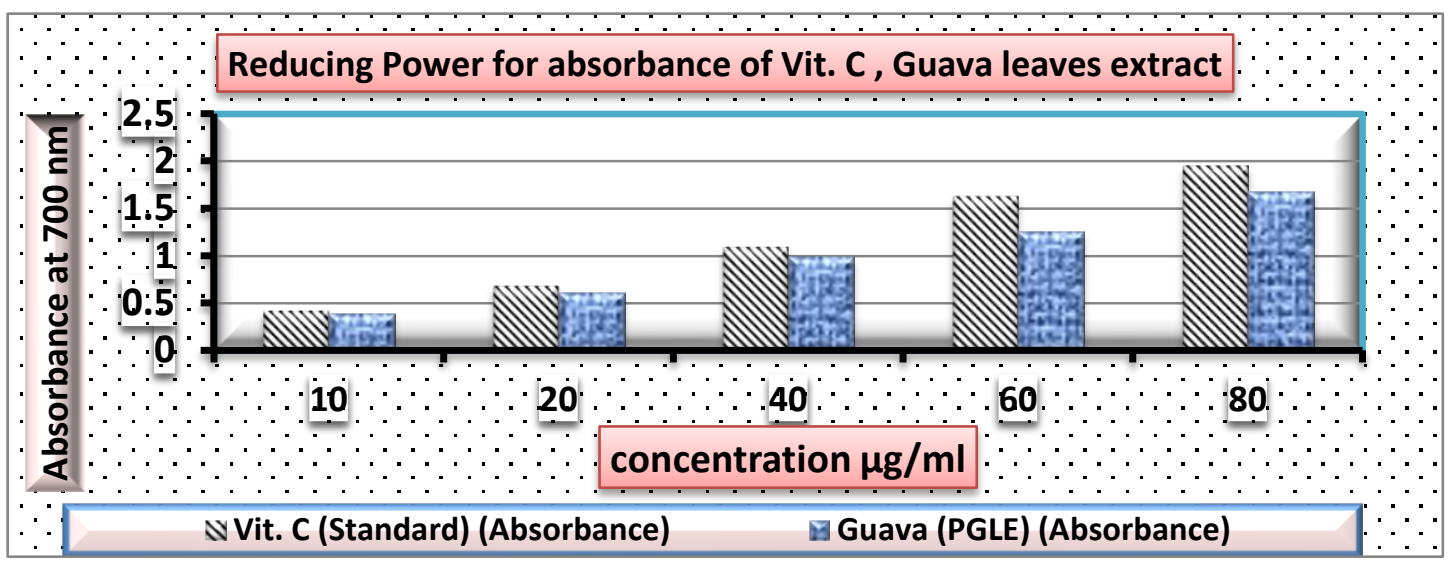

Fig. (2): Reducing power of various concentrations for guava leaves and olive leaves extract $(\mu \mathrm{g} / \mathrm{ml})$ 
Omima M. R. Abu Elez, et al.,

Table (1): Effect of graded doses of aqueous leaves extract of p. guajava on glycemic indices (fasting bl. glucose) in severe diabetic rats

\begin{tabular}{|c|c|c|c|c|c|}
\hline \multirow[t]{3}{*}{ Experimental rats } & \multirow{3}{*}{$\begin{array}{l}z \\
0 \\
\text { ग } \\
\frac{\mathbb{J}}{\omega}\end{array}$} & \multicolumn{4}{|c|}{ Fasting plasma glucose levels (mg/dl) } \\
\hline & & \multirow{2}{*}{$\begin{array}{c}\begin{array}{c}\text { Pre- Treatment } \\
\text { Blood glucose } \\
\text { levels }\end{array} \\
\text { (mg/100 ml blood) } \\
\begin{array}{c}\text { (Zero -Time) } \\
\text { Initial week }\end{array}\end{array}$} & \multicolumn{3}{|c|}{$\begin{array}{l}\text { Post - Treatment } \\
\text { Blood glucose levels } \\
\text { (mg/100 ml blood) }\end{array}$} \\
\hline & & & $2^{\text {nd }}$ weeks & $4^{\text {th }}$ weeks & $\begin{array}{l}8^{\text {th }} \text { weeks } \\
\text { Final week }\end{array}$ \\
\hline Normal Control (NC) & 6 & $84.92 \pm 6.8$ & $83.63 \pm 4.2$ & $84.34 \pm 2.3$ & $79.61 \pm 7.2$ \\
\hline Diabetic Control (DC) & 6 & $282.3 \pm 37.6$ & $396 \pm 47.1$ & $425.3 \pm 12.2$ & $465.0 \pm 27.3$ \\
\hline D + PGLE- 200 mg & 6 & $264.0 \pm 13.9$ & $169.4 \pm 5.3^{*}$ & $115.4 \pm 3.9^{\star \star}$ & $89.22 \pm 2.5^{\star \star}$ \\
\hline D + PGLE- 400 mg & 6 & $306.2 \pm 23.4$ & $138.6 \pm 3.2^{*}$ & $102.6 \pm 4.8^{\star \star}$ & $78.13 \pm 2.6^{\star \star}$ \\
\hline
\end{tabular}

Mean in the same column followed by the same letters do not differ significantly, and when the means followed by different letters differ significantly at* $(P \leq 0.05)$ between DC group \& at ${ }^{* *}(P>$ 0.001 ) between NC group and other groups, compared to pre- treatment levels.

Co-treated daily with administration of Aq. leaves extract of p.guajava significantly reduced the blood glucose levels in all the treated groups compared to the diabetic control. Glucose level in rats' model of diabetes treated daily with guava leaves extract $(400 \mathrm{mg} / \mathrm{kg} \mathrm{b.w})$ decreased to $138.6 \mathrm{mg} / \mathrm{dl}$ after 2 weeks and restored to control value $78.13 \mathrm{mg} / \mathrm{dl}$ after $8^{\text {th }}-$ weeks.

Two extracts groups had a relatively similar decrease (200 $\mathrm{mg}$ and $400 \mathrm{mg}$ ) of Aq. p. guajava leaves extract $(89.22 \pm 2.5$ $\mathrm{mg} / \mathrm{dL}$ and $78.13 \pm 2.6 \mathrm{mg} / \mathrm{dL}$ ) respectively at final week. Thus, the dose of $(200 \mathrm{mg} / \mathrm{kg}$. b.wt) sufficient for reduction in blood glucose levels.

\section{Glycosylated Hemoglobin (HbA1c \%) Values}

Maintaining glycemic control by treating well- HbA1c targets. The HbA1c levels of normal rats ranged from (5.07 \pm $0.04 \%$ and $5.11 \pm 0.02 \%$ ). HbA1c level of the control untreated group was increased an approximately 2 times (6.24 $\pm 0.33 \%)$ to $(11.4 \pm 0.28 \%)$. In current investigate at the end of $8^{\text {th }}$-weeks in clinical trial, reported that HbA1c significantly decreased from $(5.97 \pm 0.14$ $\%$ to $5.81 \pm 0.03 \%$ ) in PGLE-200 $\mathrm{mg}$ treated subjects (Table 2). At final- week after feeding, HbA1c levels of diabetic rats treated with herbal extract $(0.4 \mathrm{~g} / \mathrm{kg}$ b.wt.) was (6.34 $\pm 0.02 \%)$.

\section{Urine glucose levels in variable experimental rats}

Urine glucose measured once commonly no longer used for diagnosis or monitoring, because it's neither sensitive nor specific (Ardawi et al., 2000; and Alto, 2005). Table (3) shows glucose not detected in the urine of control rats. But diabetic untreated rats were highly glucosuria following induction of diabetic was $(+)$ increased to $(+++)$ at day 7 , then increased further to (++++) at day 14 of the experiment. Diabetic treated with Aq. PGLE- $400 \mathrm{mg}$ had initial urine glucose level (Nil) 24-hours after STZ treatment. It increased to (+) at day 7 . The diabetic with Aq. PGLE- $200 \mathrm{mg}$ treated rats had urine glucose levels of Trace and (++) at days 1 and 7 respectively after treatment 
with STZ. In this study, Aq. Guava leaves extract $(200 \& 400) \mathrm{mg} / \mathrm{kg} \mathrm{b.w/} \mathrm{day} \mathrm{were}$ equally effective in abolishing glycosuria, since there were no traces of glucose in the urine of plant leaves extract treated diabetic rats at the end of the study.

Our results were compatible with (Antai et al., 2010), when comparative effects of Rothmannia Hispida leaves extract on alloxan-induced diabetic rats. They indicated that glucose not detected in the urine of normal control, and diabetic untreated rats were glycosuria; their mean urine glucose concentration at the end of the study was significantly higher than that of the treated groups.

Effect of leaves extract on the changes of body weight gain in variable rats

The normal control rats had initial body weight of (144 $\pm 5.0 \mathrm{~g}$ ), but at end of the experiment, their body weight increased to $(173 \pm 2.3 \mathrm{~g})$. The diabetic untreated group had initial body weight of $(143 \pm 5.0 \mathrm{~g})$. Their final body weight was $(94 \pm 2.1 \mathrm{~g})$ which significantly $(P \leq 0.05)$ lower compared to the initial body weight (Table 4). The initial mean body weight of diabetic treated with PGLE-200 $\mathrm{mg}$ was $(143 \pm 4.3 \mathrm{~g})$. They had a significant $(P \leq 0.05)$ weight lost at 7 day $(129 \pm 2.1)$ prior to treatment with the extract. At the end of the experiment, their mean body weight increased significantly $(P>0.001)$ to $(153 \pm 2.5 \mathrm{~g})$. PGLE- $400 \mathrm{mg}$ treated groups, increased significantly $(P>0.001)$ to $\left(\begin{array}{ll}159 & \pm 2.3\end{array}\right)$ compared with their weights of control values at zero - time.

We noted that P.Guajava leaves have more potent in diabetic rats for improving their body weight gain, might be a result of its high ability to control high blood glucose levels. The present results showed that the STZ-induced rat model of diabetes associated with a significant decrease in weight gain. These results agree with Husni et al., (2016), who stated that STZ-induced diabetes characterized by a severe loss of body weight that explained by increase in fat and protein catabolism due to loss and ineffective utilization of glucose, and absolute or relative deficiency of insulin and decreased production of ATP and protein synthesis in all tissues.

Table (2): Effect of graded doses of aqueous leaves extract of p. guajava on HbA1c

\begin{tabular}{|l||c||c|c||}
\hline \multirow{2}{*}{ Groups } & \multirow{2}{*}{$\mathrm{N}$} & \multicolumn{2}{c||}{ Glycated Hemoglobin HbA1c (\%) } \\
\cline { 3 - 4 } & & Initial - week & Final - week \\
\hline \hline Normal control (NC) & 6 & $5.11 \pm 0.02$ & $5.07 \pm 0.04$ \\
Diabetic control (DC) & 6 & $6.24 \pm 0.33$ & $11.4 \pm 0.28$ \\
STZ+ PGET -200 mg & 6 & $5.97 \pm 0.14$ & $5.81 \pm 0.03^{\star \star}$ \\
STZ+ PGET-400 mg & 6 & $6.67 \pm 0.03$ & $6.34 \pm 0.02^{\star *}$ \\
\hline
\end{tabular}

Table (3): Urine glucose level of variable experimental rats

\begin{tabular}{|l|l|c|c|c|}
\hline Variable & \multirow{2}{*}{ N } & \multicolumn{3}{|c|}{ Urine glucose } \\
\cline { 4 - 5 } (Experimental rats) & & 1 day & 7 days & 14 days \\
\hline Normal control/NC & 6 & Nil & Nil & Nil \\
\hline Diabetic untreated/ (DC) & 6 & + & +++ & ++++ \\
\hline D + PGET-200 $\mathrm{mg} / \mathrm{kg} \mathrm{b.w/day}$ & 6 & Trace & ++ & Nil \\
\hline D + PGET-400 $\mathrm{mg} / \mathrm{kg}$ b.w/day & 6 & Nil & + & Nil \\
\hline
\end{tabular}


Omima M. R. Abu Elez, et al.,

Table (4): The effect of daily orally administration of aqueous extract of $P$. guajava leaves, within eighth- weeks on the change in body weight gain (gm) in hyperglycemic rats.

\begin{tabular}{|c|c|c|c|c|c|c|c|}
\hline \multirow[t]{3}{*}{$\begin{array}{l}\text { Experimental } \\
\text { (Groups) }\end{array}$} & & \multicolumn{6}{|c|}{$\begin{array}{l}\text { Body weight (gm.) } \\
\qquad(140: 150)\end{array}$} \\
\hline & \multirow[t]{2}{*}{$\mathbf{N}$} & \multirow{2}{*}{$\begin{array}{c}\text { Pre- } \\
\text { treatment } \\
\text { (before } \\
\text { STZ - } \\
\text { induced) }\end{array}$} & $\begin{array}{c}\text { Pre- } \\
\text { treatment } \\
\text { (after STZ }\end{array}$ & \multicolumn{4}{|c|}{ Post- treatment levels } \\
\hline & & & $\begin{array}{l}\text { 7- days } \\
M \pm S E\end{array}$ & $\begin{array}{l}2^{\text {nd }}- \\
\text { Weeks } \\
\text { M } \pm \text { SE }\end{array}$ & $\begin{array}{c}4^{\text {th }} \text {-weeks } \\
M \pm S E\end{array}$ & $\begin{array}{c}6^{\text {th }}-\text { weeks } \\
M \pm S E\end{array}$ & $\begin{array}{c}8^{\text {th }}-\text { week } \\
M \pm S E\end{array}$ \\
\hline $\begin{array}{l}\text { Normal Control } \\
\text { (NC) }\end{array}$ & 6 & $144 \pm 5.0$ & $148 \pm 1.2$ & $151 \pm 1.1$ & $154 \pm 1.3$ & $160 \pm 2.0$ & $173 \pm 2.3$ \\
\hline $\begin{array}{l}\text { Diabetic } \\
\text { Control(DC) }\end{array}$ & 6 & $143 \pm 5.0$ & $137 \pm 1.0$ & $130 \pm 0.8$ & $126 \pm 2.0$ & $107 \pm 1.6$ & $94 \pm 2.1$ \\
\hline STZ +PGLE-200 mg & 6 & $143 \pm 4.3$ & $129 \pm 2.1^{*}$ & $131 \pm 1.4^{\star}$ & $133 \pm 2.3^{*}$ & $140 \pm 2.4$ ** & $153 \pm 2.5$ ** \\
\hline STZ+ PGLE-400 mg & 6 & $145 \pm 5.0$ & $132 \pm 1.0^{*}$ & $135 \pm 2.1^{*}$ & $140 \pm 2.1^{\star \star}$ & $147 \pm 1.6^{\star \star}$ & $159 \pm 2.3^{\star \star}$ \\
\hline
\end{tabular}

Mean in the same column followed by the same letters do not differ significantly, and when the means followed by different letters differ significantly at* $(P \leq 0.05)$ between $D C$ group and other groups or at $^{\star *}(P>0.001)$ between NC group and other groups.

\section{Conclusion}

In conclusion, this study revealed that aqueous extracts of psidium guajava leaves possess significant anti-diabetic and effective in lowering blood glucose level, but lack hypoglycemic effect on hyperglycemic rats.

\section{REFERENCES}

Ahmadvand, H., A. Noori, G.M. Dehnoo, Sh. Bagheri and A.R. Cheraghi (2014). "Hypoglycemic, hypolipidemic and antiatherogenic effects of oleuropein in alloxan-induced Type 1 diabetic rats" Asian Pac J Trop Dis; 4(1) : 421425.

Altalhi, A S., M.A. Hassan, D. Al-Harthi, Sh. Allah and S.F. Alharbi (2018). "Wild olive leaf extracts up regulate insulin-signaling gene expression in diabetic mice" Global Advanced Research Journal of Agricultural Science; 7 (4): 104 -109.
Alto, W. A. (2005). "No need for glycosuria/proteinuria screen in pregnant women". J. Fam. Pract.; 54 (11): $978-983$.

Antai, A.B., O.E. Ofem, O. J. Nwosu, S. O. Ukafia, K. C. lyadi, R. Nia and E.E. Osim (2010). "Comparative effects of rothmannia hispida leaves extract and protamine-zinc insulin on alloxaninduced diabetic rats." Afr. J. Biomed. Res.; 13: $47-54$.

Ardawi, M. S., H. A. Nasrat, H. S. Jamal, H. M. Al Sagaaf and B. E. Mustafa (2000). "Screening of gestational diabetes mellitus in pregnant females" Saudi Med J. 21: 155-160

Benzie, I. F. and J. J. Strain (1999). "Ferric reducing/antioxidant power assay: direct measure of total antioxidant activity of biological fluids and modified version for simultaneous measurement of total antioxidant power and ascorbic acid 
concentration". Methods in

Enzymology; 299: 15 - 27.

CDC, (2014). "Center for Disease Control and Prevention" National Diabetes Statistics Report: Estimates of diabetes and its burden by epidemiologic estimation methods in the United States, Atlanta, GA: U.S. Department of Health and Human Services; 1 - 12.

CDC, (2015). "Centers for Disease Control and Prevention". Age adjusted rates of diagnosed diabetes per 100 civilian, non-institutionalized populations by sex, United State; 1980 - 2014.

Chandra, S., S. Khan, B. Avula, H. Lata, M. H. Yang, M. A. ElSohly and I. A. Khan (2014). "Assessment of total phenolic, flavonoid content, antioxidant properties, and yield of aeroponically, and conventionally grown leafy vegetables and fruit crops". A comparative study, Evid Based Complement Alternat Med.

Chang, C., M. Yang, H. Wen and J. Chern (2002). "Estimation of total flavonoid content in propolis by two complementary colorimetric methods" J. Food Drug Analaysis; 10: 178 -182.

El-Sayed, S. M. and Said S. M. Mehraban (2017). "Antioxidant and insecticidal effect of some plant extracts against Callosbruchus maculates (Coleoptera: Bruchidae), Chemistry Research Journal; 2 (3): 133 - 143.

Ferreira, I., P. Baptista, M. Vilas-Boas and L. Barros (2007). "Free-radical scavenging capacity and reducing power of wild edible mushrooms from northeast Portugal: Individual cap and stipe activity". Food Chem., 100: 1511-1516.

Godebo, A., M. Eyasu and M. Negussu (2018). "Hypoglycemic and antihyperglycemic effect of leaves extracts of psidium guajava in normoglycemic and streptozotocininduced diabetic MICE". International Journal of Pharmacognosy, Addis Ababa, Ethiopia: 69.75, Projected Impact Factor; 0.51

Grasas, A., M. Abd El-Moneim, R. Afify and El- Hossam (2018). "In vivo correlation of olive leaves extract on some oxidative stress markers in streptozotocin-induced diabetes mellitus".

Husni, A., D. Purwanti and Ustadi (2016). "Blood glucose level and lipid profile of streptozotocin-induced diabetes rats treated with sodium alginate from Sargassum crassifolium" Journal of Biological Sciences; 16 (3): 58-64

IDF, (2012). "IDF Diabetes Atlas 5". International Diabetes FederatioN; 12.

Naseer, S., Sh. Hussain, N. Naeem, M. Pervaiz and M. Rahman (2018). "Value of Psidium guajava (guava)" Clinical Phytoscience; 4: 32

NCCLS (National Committee for Clinical Laboratory Standard), (1992). "GP16A/ Routine urinalysis and collection transportation and preservation of urine specimens"; Trntative Guideline; 12 (26), Ec.

Olaniyan, M F. (2017). "Cholesterol lowering effect of guava leaves (Psidium guajava) extract on egg yolk induced hypercholesterolaemic rabbits". JOBAN; 7 (1): 24 - 28.

Rodríguez, M. L., J. M. Estrela and A. L. Ortega (2014). "Natural polyphenols and apoptosis induction in cancer therapy" Carcinogene Mutagene; 6: 1 4.

Rouseff, R.L., E.O. Onagbola, J.M. Smoot and L.L. Stelinski (2011). "Sulfur volatiles in guava (psidium guajava) leaves": Possible defense 
Omima M. R. Abu Elez, et al.,

mechanism". J Agric Food Chem., 56: 8905- 8910.

Tietz, N.W. (1999). "Textbook of Clinical Chemistry", W.B. Saunders Company; 794 - 7795

Trinder, P. (1969). "Determination of glucose in body fluids" Ann. Clin. Biochem; 620: 24 - 33.

Tsao, R. and R. Yang (2003). "Optimization of a new mobile phase to know the complex and real polyphenolic composition: towards a total phenolic index using highperformance liquid chromatography"
Journal of Chromatography A; 1018 (1): $29-40$.

Verma, M., G.K. Rai and D. Kaur (2018). "Effect of extraction solvents on phenolic content and antioxidant activities of Indian gooseberry and guava" International Food Research Journal., 25 (2): 762-768.

WHO, (2004). "WHO guidelines on safety monitoring of herbal medicines in pharmacovigilance systems". World health organization, Geneva, Switzerland Akerele, O- 1993, Summary of WHO guidelines for the assessment of herbal medicines". Herb. Gram; 28: 13-19. 
تأثير المستخلص المائى لأوراق الجوافة كمضاد للاءاء السكرى

أميمة محمد رشاد أبو العز (')، مصطفى عبدالله همام(؟)، فؤاد مطاوع الشوني(؟)

قسم الكيمياء الحيوية الباثولوجية - للتحاليل الطبية - مستثفى الروضة المركزي - دمياط

قسم الكيمياء الحيوية - كلية الزراعة - جامعة المنوفية الكية الهوله

الملخص العربي

Hyperglycemia

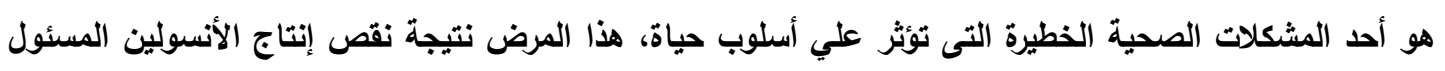

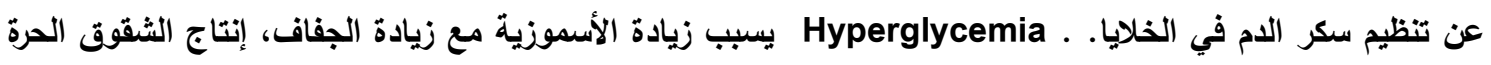

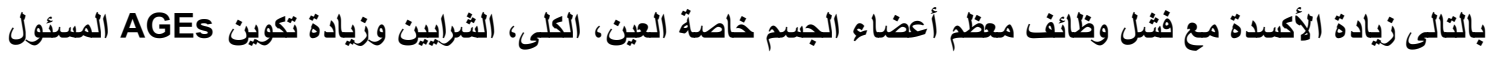
عن المضاعفات الصغرى والكبرى لأمراض القلب المصاحبة للمرض السكرى..! يمكن السيطرة على هذا المرض بتثخيص

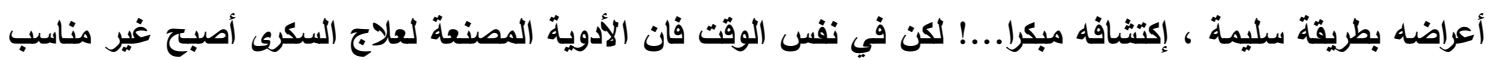

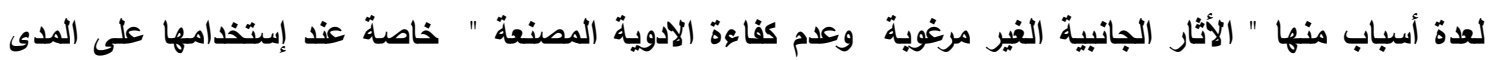

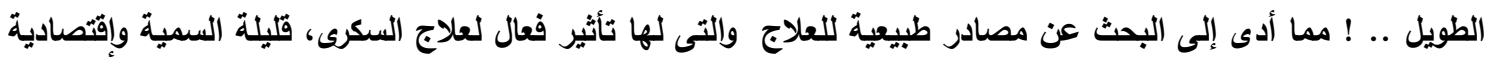
كما تقلل الأثار الجانبية ولا تسبب أى مشكلات صحية من بينها أولق الجوافة كبائل طبيعية. أهداف الدراسة: التحقى من التأثير الحيوى لأولق الجوافة كمضاد للاءاء السكرى وذلك بإنخفاض مستوي سكر الدم وغيرها من مؤشرات السكرى إلى المعدل الطبيعى باجراء التحليل البيوكيميائى لفئران التجرية المختبرة.....!

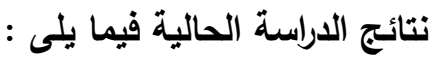
• أوضحت النتائج أن المستخلص الميثانولى لأورلق الجوافة غنى بالمركبات الفينولية، غنية بالفلافونويد.

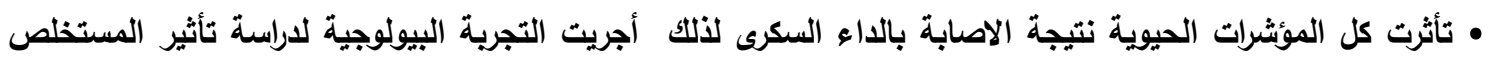

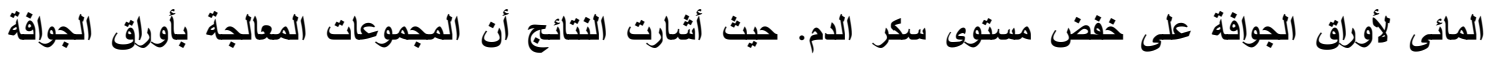

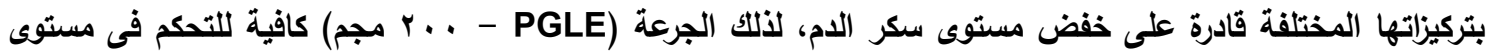

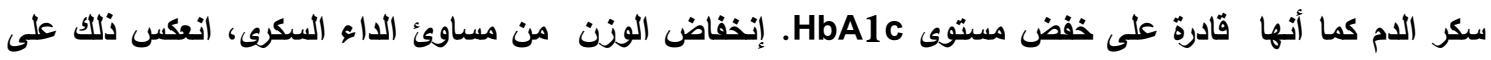

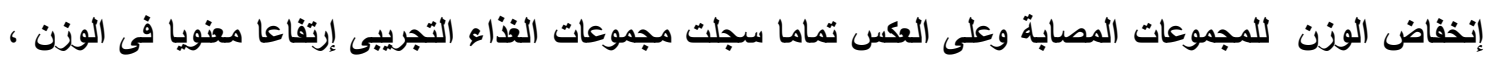

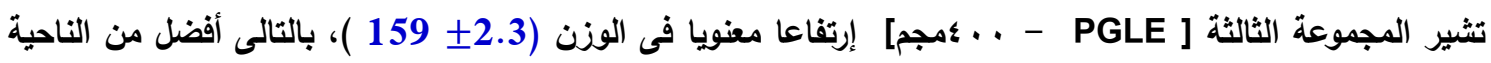

الغذائية.

الخاتمة: أوضحت النتائج ان مستخلص أولق الجوافة مؤثر على خفض مستوى سكر الام فى فئران التجرية حيث يضم العلاج التحكم فى السكرى من أعراض ومنع حدوث مضاعفات مع تقليل انخفاض السكر عن المعدل الطبيعى.

أسماء السادة المحكمين

كلية العلوم - جامعة المنوفية

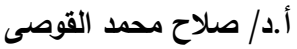

أ.د/ مدحت مصطفى أبوزيد كلية الزراعة - جامعة المنوفية 